\title{
Morphine Metabolism in Human Skin Microsomes
}

\author{
S. Heilmann ${ }^{a} \quad$ S. Küchler ${ }^{b} \quad$ M. Schäfer-Korting ${ }^{a}$

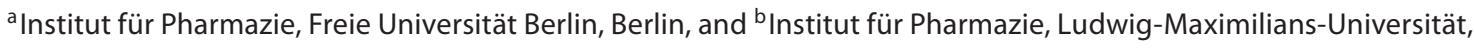 \\ Munich, Germany
}

\section{Key Words}

Morphine $\cdot$ UGT2B7 $\cdot$ Morphine glucuronidation - Skin

metabolism $\cdot$ Human skin microsomes

\begin{abstract}
For patients with severe skin wounds, topically applied morphine is an option to induce efficient analgesia due to the presence of opioid receptors in the skin. However, for topical administration it is important to know whether the substance is biotransformed in the skin as this can eventually reduce the concentration of the active agent considerably. We use skin microsomes to elucidate the impact of skin metabolism on the activity of topically applied morphine. We are able to demonstrate that morphine is only glucuronidated in traces, indicating that the biotransformation in the skin can be neglected when morphine is applied topically. Hence, there is no need to take biotransformation into account when setting up the treatment regimen.
\end{abstract}

Copyright $\odot 2012$ S. Karger AG, Base

\section{Introduction}

Severe skin wounds, as in the case of burn patients, are associated with strong pain and very often require treatment with systemically applied opioids. This treat- ment can cause typical opioid-related adverse effects such as constipation or sedation. The presence of opioid receptors in peripheral structures like sensory nerve endings, melanocytes, normal human keratinocytes and fibroblasts [1-4] in principle allows for a treatment with topically applied opioids in order to gain efficient analgesia and to avoid systemic side effects. Several clinical studies on topically applied opioids in severe skin wounds have shown that efficient analgesic effects can be obtained [for review, see 5, 6]. Nevertheless, the failing success in some studies raises the question of inadequate morphine delivery or local morphine biotransformation [for review, see 5]. Biotransformation of morphine in the skin has not yet been studied although skin metabolism has been shown to activate or inactivate xenobiotics [7-9], which is a relevant parameter for the efficiency and tolerability of a treatment regimen. In the liver, morphine is mainly metabolized to morphine-3and morphine-6-glucuronide by UDP-glucuronosyltransferase (UGT)2B7 [10]. Expressed in traces in normal human dermal fibroblasts and normal human keratinocytes on the mRNA level [11, 12], UGT2B7 may also metabolize morphine when applied onto the skin. Moreover, the relevance of strongly expressed and active UGT1 [13] needs to be considered as a potential source of morphine glucuronidation. 


\section{Materials and Methods}

\section{Materials/Equipment}

Human skin microsomes were obtained from Biopredic International (Rennes, France); liver microsomes (BD UltraPool ${ }^{\mathrm{TM}}$ HLM 150) and UGT reaction mix solution were purchased from BD Biosciences (Woburn, Mass., USA); $\beta$-glucuronidase type HP-2 was obtained from Sigma-Aldrich (Schnelldorf, Germany), and morphine $\mathrm{HCl}$ and hydromorphone $\mathrm{HCl}$ were purchased from Fagron (Hamburg, Germany). Stock solutions for HPLC analysis and glucuronidation assay were prepared in a mixture of $0.05 \mathrm{M}$ potassium hydrogen phosphate buffer ( $\mathrm{pH} 4.9)$ and acetonitrile $(90: 10)$ and remained stable at $-20^{\circ} \mathrm{C}$ for up to 3 months. The chemicals were of highest quality.

For morphine quantification HPLC instruments from Merck Hitachi (Tokyo, Japan) were used (autosampler L-7200, interface D-7000, pump L-7100, UV detector L-7400, fluorescence detector L-7480 and HSM software D-7000). Column (LiChhroCART ${ }^{\circledR}$ 250-4 RP-8.5 $\mu \mathrm{m}$ ) and precolumn (LiChroCART 4-4) were purchased from Merck (Darmstadt, Germany).

\section{Methods}

Morphine Glucuronidation Assay

UGT reaction mix solution A (containing uridine $5^{\prime}$ diphospho-glucuronic acid, UDPGA, $2 \mathrm{mM}$ ), UGT reaction mix solution $\mathrm{B}$ (containing Tris $\mathrm{HCl} 50 \mathrm{mM}, \mathrm{MgCl}_{2} 8 \mathrm{~mm}$, alamethicin $25 \mu \mathrm{g} / \mathrm{ml}$; final concentrations) and morphine stock solution (either 0.1 or $0.01 \mathrm{mM}$ in incubation) were preincubated for $5 \mathrm{~min}$ at $37^{\circ} \mathrm{C}$. Human skin microsomes $(200 \mu \mathrm{g})$ were added for a final volume of $200 \mu \mathrm{l}$. After an incubation period of $2 \mathrm{~h}$ at $37^{\circ} \mathrm{C}$ the reaction was stopped by the addition of $100 \mu$ lice-cold $18.5 \% \mathrm{HCl}$. After centrifugation at $10,000 \mathrm{~g}$ for $2 \mathrm{~min}$, the supernatant was removed and neutralized using $1 \mathrm{~N} \mathrm{NaOH}$. Pooled liver microsomes were used as a positive control. Blank controls (no microsomes added) and negative controls (no morphine added) were also studied.

For the quantification of metabolites (morphine-3- and morphine-6-glucuronide) a $\beta$-glucuronidation assay was performed. The samples were divided into two aliquots. One aliquot was incubated for $72 \mathrm{~h}$ at $37^{\circ} \mathrm{C}$ with a double volume of $400 \mathrm{U} / \mathrm{ml} \beta$ glucuronidase in McIlvaine's buffer (pH 5.0) and the other with McIlvaine's buffer only. Reaction was stopped by adding $1 \mathrm{~N}$ $\mathrm{NaOH}$ and the $\mathrm{pH}$ was adjusted to 9.5. The morphine content was determined after ethyl acetate extraction using HPLC UV/fluorescence measurement and hydromorphone as the internal standard. The liquid phase was potassium hydrogen phosphate buffer $(\mathrm{pH} 4.9 ; 92 \%)$ and acetonitrile (8\%). Fluorescence intensity (extinction $235 \mathrm{~nm}$, emission $345 \mathrm{~nm}$ ) was measured for the quantification of morphine (retention time: $6.5 \mathrm{~min}$ ) and UV detection $(210 \mathrm{~nm})$ was used for hydromorphone (retention time: $10.5 \mathrm{~min})$. The range of linearity is $0.1-100 \mu \mathrm{M}$ for morphine and $1-100 \mu \mathrm{M}$ for hydromorphone $\left(\mathrm{R}^{2} \geq 0.99\right)$, respectively. Interday and intraday variabilities are suitable $\left(\mathrm{SD}_{\text {rel }} \leq 12 \%\right)[14]$. For the quantification of the metabolites the following equation was used:

$$
[\mathrm{ME}]=\left([\mathrm{Mor}]_{+}-[\text {Mor }]_{-}\right) \times 2
$$

$[\mathrm{ME}]=$ amount of metabolites; $[\text { Mor }]_{+} /[\mathrm{Mor}]_{-}=$the amount of morphine with and without incubation with $\beta$-glucuronidase.

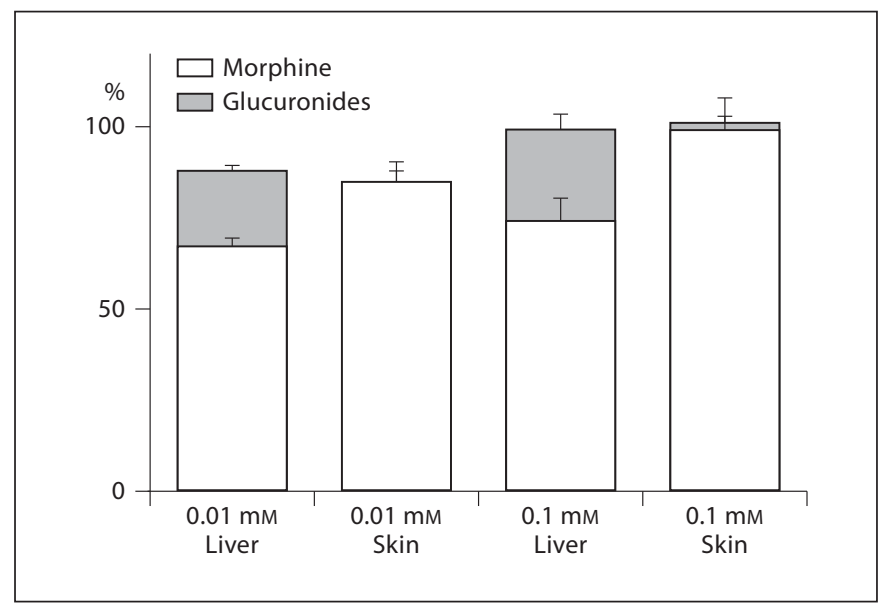

Fig. 1. Morphine glucuronidation after $2 \mathrm{~h}$ incubation with 200 $\mu \mathrm{g}$ of liver or skin microsomes. The liver microsomes metabolized morphine extensively, whereas the skin microsomes transformed morphine only to a minor extent.

\section{Results and Discussion}

\section{Morphine Metabolism}

For the development of a drug for topical use it is important to take the biotransformation in the skin into account. The biotransformation of morphine in the liver leads to the formation of the active metabolite morphine6-glucuronide and the inactive morphine-3-glucuronide. UGT2B7 is the dominating enzyme responsible for the glucuronidation of morphine, but an involvement of UGT1A1, 1A3, 1A6, 1A8, 1A9 and 1A10 is also possible. Furthermore, the formation of normorphine by CYP3A4 and CYP2C8 has to be considered [10]. PCR studies revealed UGT2B7 expression in extra hepatic tissues like the kidneys, mammalian glands, lung and the small intestine [16]. To date almost nothing is known about the expression of UGT2B7 in the skin. The enzyme expression on mRNA level [11] in traces in normal human keratinocytes and normal human dermal fibroblasts, as well as in the human epidermis and in the Episkin ${ }^{\mathrm{TM}}$ skin model [16], indicates that morphine may be biotransformed in the skin - but most likely to a lower extent. Moreover, morphine is not biotransformed in human cadaver skin which was obtained $24-48 \mathrm{~h}$ postmortem [17]. Thus, the storage of the skin may reduce enzyme activity significantly.

In order to confirm the expected poor morphine metabolism in the skin we investigated morphine glucuronidation using human skin microsomes. One batch was 
obtained from a female donor ( $66 \mathrm{a})$; the other batch represented a pool of two female donors ( $36 \mathrm{a}$ and $56 \mathrm{a}$ ). In accordance with previous results [11], we investigated two morphine concentrations in the microsome assay. Microsomal glucuronidation assays are commonly used for biotransformation studies of chemicals and active pharmaceutical substances such as morphine, acetaminophen and testosterone $[18,19]$. In order to ensure that both types of microsomes are active, testosterone was incubated to prove the CYP activity (data not shown). We performed a $\beta$-glucuronidase assay for the quantification of morphine-6- and morphine-3-glucuronide; the distinction between both metabolites is not possible with this method. Incubation $(2 \mathrm{~h})$ of microsomal protein $200 \mu \mathrm{g}$ and 0.1 or $0.01 \mathrm{mM}$ of morphine resulted in negligible metabolite formation $(1.7 \pm 4.5$ and $0.2 \pm 6.3 \%$, respectively), whereas liver microsomes generated $24.6 \pm 9.4$ and $20.6 \pm 2.8 \%$ metabolites (fig. 1). Thus, the results of the mRNA expression study were confirmed: morphine is only marginally biotransformed in human skin. However, the poor morphine glucuronidation in human skin clearly differs from the 4-methylumbelliferone metabolism [13], a preferential substrate of UGT1 which is well expressed in reconstructed human epidermis. Since skin microsomes are not only comprised of UGT2B7 but also of all other enzymes present in the skin, major morphine inactivation after topical application can be excluded. Yet hepatic biotransformation will metabolize percutaneously absorbed morphine. Although reconstructed human epidermis was proven to be predictive for human skin with respect to phase I [20] and phase II [13] biotransformation, morphine metabolism in the skin should be investigated further in in vivo studies to support our findings. This would involve using the microdialysis technique to measure the formation of morphine 3- and morphine-6-glucuronide after the topical application.

\section{Conclusion}

Topically applied morphine is an option to achieve efficient pain relief for patients with severe skin wounds associated with severe pain. Since morphine is only metabolized in traces in the skin, biotransformation can be neglected for the development of a topical morphine formulation.

\section{Acknowledgements}

Sarah Heilmann was a scholarship holder of the German Dr. Hilmer Stiftung.

\section{References}

1 Bigliardi PL, Bigliardi-Qi M, Buechner S, Rufli T: Expression of mu-opiate receptor in human epidermis and keratinocytes. J Invest Dermatol 1998;111:297-301.

2 Bigliardi PL, Tobin DJ, Gaveriaux-Ruff C, Bigliardi-Qi M: Opioids and the skin - where do we stand? Exp Dermatol 2009;18:424430.

3 Salemi S, Aeschlimann A, Reisch N, Jungel A, Gay RE, Heppner FL, Michel BA, Gay S, Sprott H: Detection of kappa and delta opioid receptors in skin - outside the nervous system. Biochem Biophys Res Commun 2005;338:1012-1017.

4 Stein C, Machelska H, Binder W, Schäfer M: Peripheral opioid analgesia. Curr Opin Pharmacol 2001;1:62-65.

5 Farley P: Should topical opioid analgesics be regarded as effective and safe when applied to chronic cutaneous lesions? J Pharm Pharmacol 2011;63:747-756.

6 Stein C, Küchler S: Non-analgesic effects of opioids: peripheral opioid effects on inflammation and wound healing. Curr Pharm Des 2012, PMID: 22747536. E-pub ahead of print.
7 Lombardi Borgia S, Schlupp P, Mehnert W, Schäfer-Korting M: In vitro skin absorption and drug release - a comparison of six commercial prednicarbate preparations for topical use. Eur J Pharm Biopharm 2008;68:380389.

8 Baron JM, Holler D, Schiffer R, Frankenberg S, Neis M, Merk HF, Jugert FK: Expression of multiple cytochrome P450 enzymes and multidrug resistance-associated transport proteins in human skin keratinocytes. J Invest Dermatol 2001;116:541-548.

9 Chouinard S, Yueh MF, Tukey RH, Giton F, Fiet J, Pelletier G, Barbier O, Belanger A: Inactivation by UDP-glucuronosyltransferase enzymes: the end of androgen signaling. J Steroid Biochem Mol Biol 2008;109:247-253.

10 Maurer HH, Sauer C, Theobald DS: Toxicokinetics of drugs of abuse: current knowledge of the isoenzymes involved in the human metabolism of tetrahydrocannabinol, cocaine, heroin, morphine, and codeine. Ther Drug Monit 2006;28:447-453.
11 Küchler S, Wolf NB, Heilmann S, Weindl G, Helfmann J, Yahya MM, Stein C, SchäferKorting M: 3D-wound healing model: Influence of morphine and solid lipid nanoparticles. J Biotechnol 2010;148:24-30.

12 van Ingen IL, Jansen MM, Barrera P: Topical opioids for painful ulcers in systemic sclerosis. Ann Rheum Dis 2008;67:427.

13 Götz C, Pfeiffer R, Tigges J, Ruwiedel K, Hubenthal U, Merk HF, Krutmann J, Edwards RJ, Abel J, Pease C, Goebel C, Hewitt N, Fritsche E: Xenobiotic metabolism capacities of human skin in comparison with a 3Depidermis model and keratinocyte-based cell culture as in vitro alternatives for chemical testing: phase II enzymes. Exp Dermatol 2012;21:364-369.

14 Heilmann S: Opioide zur lokalen Ausschaltung schwerster Schmerzen bei Verletzung der Haut. Berlin, Freie Universität Berlin, 2011.

15 Turgeon D, Carrier JS, Levesque E, Hum DW, Belanger A: Relative enzymatic activity, protein stability, and tissue distribution of human steroid-metabolizing UGT2B subfamily members. Endocrinology 2001;142: 778-787. 
16 Luu-The V, Ferraris C, Duche D, Belanger P, Leclaire J, Labrie F: Steroid metabolism and profile of steroidogenic gene expression in episkin: high similarity with human epidermis. J Steroid Biochem Mol Biol 2007;107: 30-36.

17 Roy SD, Hou SY, Witham SL, Flynn GL: Transdermal delivery of narcotic analgesics: comparative metabolism and permeability of human cadaver skin and hairless mouse skin. J Pharm Sci 1994;83:1723-1728.
18 Hara Y, Nakajima M, Miyamoto K, Yokoi T: Morphine glucuronosyltransferase activity in human liver microsomes is inhibited by a variety of drugs that are co-administered with morphine. Drug Metab Pharmacokinet 2007;22:103-112.

19 Fisher MB, Campanale K, Ackermann BL, VandenBranden M, Wrighton SA: In vitro glucuronidation using human liver microsomes and the pore-forming peptide alamethicin. Drug Metab Dispos 2000;28:560566.
20 Götz C, Pfeiffer R, Tigges J, Blatz V, Jäckh C, Freytag EM, Fabian E, Landsiedel R, Merk HF, Krutmann J, Edwards RJ, Pease C, Goebel C, Hewitt N, Fritsche E: Xenobiotic metabolism capacities of human skin in comparison with a 3D epidermis model and keratinocyte-based cell culture as in vitro alternatives for chemical testing: activating enzymes (phase I). Exp Dermatol 2012;21: 358-363. 